\title{
Vocational Student Teachers' Self-Reported Experiences in Creating ePortfolios
}

\author{
Anne-Maria Korhonen ${ }^{1,2 \star}$, Sanna Ruhalahti ${ }^{4}$, Minna Lakkala ${ }^{3}$, \\ Marjaana Veermans ${ }^{1}$ \\ ${ }^{1}$ University of Turku, Faculty of Education, Department of Teacher Education, \\ Assistentinkatu 5, 20014 Turku, Finland \\ ${ }^{2}$ Häme University of Applied Sciences, School of Professional Teacher Education, \\ Visamäentie 35 A, 13100 Hämeenlinna, Finland \\ ${ }^{3}$ University of Helsinki, Faculty of Educational Sciences, \\ PL 9 (Siltavuorenpenger 1A), 00014 Helsinki, Finland. \\ ${ }^{4}$ Tampere University of Applied Science, Pedagogical Innovations, Kuntokatu 3, \\ 33520 Tampere, Finland
}

Received: 08.09.2019, Accepted: 20.04.2020, Published: 05.11.2020

\begin{abstract}
Context: The context of this study is vocational teacher education and the participants are vocational student teachers studying part-time in a blended learning setting. They represent several disciplines of vocational education and training. The vocational teacher studies take one year and are 60 credits. The study relates to the discussion of vocational education and training and teachers' competencies which they are transferring to their students by sharing their knowledge of their subject area and working practices. This study is an exploration of one of these working practices making competences visible in a digital format.
\end{abstract}

Approach: Student teachers' descriptions of their practices and recommendations of supportive methods for composing an ePortfolio are reviewed and their motivation to compose an ePortfolio is studied as a part of the Personal Learning Environment (PLE) philosophy.

Findings: The data revealed some typical practices, such as creating an ePortfolio (the most popular ways of doing this were recording reflections in a learning diary and using digital tools to document artefacts) and demonstrating vocational teachers' competence in an

Corresponding author: anne-maria.korhonen@hamk.fi

ISSN: $2197-8646$

http://www.ijrvet.net

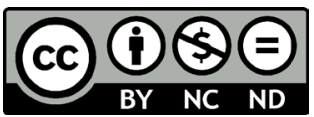


ePortfolio (understanding the difference between workspace and showcase portfolios and what kinds of competences to document). The recommendations mentioned by participants were supportive methods of composing an ePortfolio (collaborative learning processes with peers, lecturers' feedback and assessment and clear instructions) as well as methods of displaying vocational teachers' competence (e.g. orientation to ePortfolio work using learning objectives and assessment criteria for ePortfolios). Participating student teachers were motivated to work with ePortfolios in various ways and expressed an intrinsic motivation to pursue personal growth and become a vocational teacher.

Conclusions: The study revealed vocational student teachers' perceptions of scaffolding and motivational orientations to make their competences visible through ePortfolios. These can be used to design scaffolding methods to support students' ePortfolio activities. ePortfolios are used as a study method to promote student teachers' career development and personal growth and to help them acquire teacher competencies.

Keywords: ePortfolio, Motivation, PLE, Scaffolding, Self-Determination Theory, Vocational Student Teacher, Vocational Education and Training, VET

\section{Introduction}

Personalised learning environments (PLEs) are a contemporary approach to organising learning in a digital learning environment. The requirements for PLEs are that individuals may use any web tools, networks and formal and informal learning processes they desire in order to achieve the competencies required in today's working world (Fiedler \& Väljataga, 2013; Wheeler, 2015). Creating ePortfolios has become a format of studying in personal learning environments. Barrett (2010) divided ePortfolios into two types: 1) A workspace portfolio created through a process of composing, collecting and depositing artefacts for learning purposes; and 2) a showcase portfolio as a method of documenting one's achievements. Using ePortfolios during learning processes and demonstrating practical mastery of competencies has given rise to new requirements for scaffolding the process.

Previous research has shown that creating an ePortfolio for learning purposes or documenting one's competencies is not easy for student teachers (Korhonen et al., 2019b; Parker et al., 2012; Plaisir et al., 2011). In their study, Parker et al. (2012) asked elementary education student teachers how to make an ePortfolio process meaningful: The respondents identified several significant themes, such as scope, guidance, timing, alignment with standards, reflection and growth, and making ePortfolios visible to a wider audience. Plaisir et al. (2011) discovered that student teachers needed more support from faculty and more time to study as they work on their ePortfolios. Korhonen et al. (2019b) discovered that vocational student teachers were unable to demonstrate their competencies in an ePortfolio because they lacked 
the necessary knowledge or capability to do so, particularly with regard to their pedagogical competencies, digital skills and personal development as vocational teachers. More effort is needed to train student teachers in how to implement ePortfolios as a part of their studies and to demonstrate their competencies.

The current study is in the context of vocational teacher education. Vocational teachers' competencies are a complex combination of pedagogical knowledge and applied occupational practices they teach to their students (Papier, 2019; Korhonen et al., 2019a; Korhonen et al., 2019b). The occupational practices require that vocational teachers understand and have connections to workplaces in order to prepare students to enter the working world. Nowadays, employees are required to constantly improve their performance to keep up with a constantly changing working life. Teachers need methods to guide their students in acquiring these competencies. Papier (2019) argued that these tools must be the main focus of a curriculum of vocational teacher education. Korhonen et al. (2019b) suggested that in order to advance one's own professional learning, one must first be supported in creating an ePortfolio during studies and second in continuing to collect and demonstrate evidence of one's competencies. ePortfolios are also a method of demonstrating one's competencies to different audiences, which is useful when applying for a job or in making a company's competencies visible to customers (Cambridge, 2008).

Scaffolding is considered to be just the right amount of support for students to enable them to achieve their learning objectives. It is not intended to be permanent support but should fade as the student becomes a self-regulated learner (Puntambekar \& Hübscher, 2005). Chittum (2018) used an ePortfolio as a reflective learning diary written in MS Word. In other educational contexts, ePortfolios have been found to be a valuable means of fostering students' reflective skills, which are then showcased in mastery-oriented (workspace) and performance-oriented (showcase) portfolios (Cheng \& Chau, 2013). The studies mentioned above did not provide an answer as to which practices and supportive methods personally motivate students to create an ePortfolio to demonstrate their competencies. Only Korhonen et al. (2019a) and Korhonen et al. (2019b) investigated portfolios in PLE settings; in Chittum's (2018) and Cheng's and Chau's (2013) studies the digital tools were chosen by educational institutes.

Barrett (2007) and Masters (2013) argued that scaffolding ePortfolios can also enhance intrinsic motivation to continue ongoing learning throughout one's career. Chittum (2018) concluded that making an ePortfolio can significantly increase the usefulness of studentteacher training. Chye et al. (2012) concluded that teacher students with more self-determined forms of motivation had a more positive attitude toward using ePortfolios in their learning processes.

This study is an exploration of scaffolding activities which help students develop competencies by working on ePortfolios, a process considered to be part of distributed scaffolding 
(Tabak, 2004). Intrinsic and extrinsic motivations to learn (Ryan \& Deci, 2000) will also be explored, as both scaffolding and motivation are considered important in the context of vocational education and training and in the professional world of work. Sociocultural theory was chosen as the framework for the study as it is based on cultural tools which are used in a social world where learning takes place in social practices in communities (Lave \& Wenger, 1991; Säljö, 2009) by interacting with more knowing people, and with peers (Vygotsky, 1978). As Lave and Wenger (1991, p. 52) explain "persons, actions, and the world are implicated in all thought, speech, knowing, and learning."

\section{Study Aim and Research Questions}

The aim of the study is to identify the methods of scaffolding which help students develop competencies by working on ePortfolios. In the investigated setting ePortfolios were a part of student teachers' PLEs. The research questions were:

1. What kinds of practices do student teachers use to make an ePortfolio?

2. What kinds of scaffolding do student teachers recommend as important during the process of creating an ePortfolio?

3. What motivates student teachers to create an ePortfolio.

\section{Theoretical Frameworks}

\subsection{Scaffolding Organised by a Lecturer}

The term scaffolding in an educational sense was coined by Wood et al. (1976) in the context of educating children. The concept is still relevant in education because it represents the amount of support a student requires to attain set learning objectives. Scaffolding is sometimes used synonymously with the word support (Puntambekar \& Hübscher, 2005). Stone's (1998) concept of scaffolding methods necessitates the assumption that learning goals are understood by students and teachers assisting students according to their diagnosis of a student's skill level, was adapted to this study. Scaffolding includes the idea that support is temporary and should be faded away when the student is able to learn independently (Stone, 1998).

Collaborative learning with peers has been proven to be a successful method of learning by utilising small groups to construct knowledge (Michaelsen \& Sweet, 2011). Scaffolding may be collaborative when students participate in guiding their peers (Donato, 1994); it can 
also be led by several scaffolding providers, but in such cases, it should be organised by a lecturer as part of instructional management. For instance, scaffolding can be organised as part of a collaborative learning assignment using a digital learning environment (Lajoie, 2005; Tabak, 2004) or even by stakeholders' feedback during practical training. These scenarios require lecturers to create different kinds of meaningful assignments (Dabbagh, 2003). Tabak (2004) suggested utilising the idea of a synergistic scaffold which includes different kinds of support that complement each other to serve a single performance or goal. Walqui (2006) offered a similar definition of scaffolding implementing Vygotsky's and Van Lier's (as cited in Walqui 2006) ideas that the sources of scaffolding are: 1) Experts (e.g. teachers), 2) peers in collaborative knowledge construction, 3) peer-learning while assisting also lower-level learners, and 4) working alone by utilising inner resources and experiences.

De Olivieira and Athanases (2017) suggested that a scaffolding framework comprises the aspects of whom to scaffold, for what purpose(s) and how. In this study of scaffolding, student teachers' task to make ePortfolios was the setting through which to define what to scaffold and for what purposes; the question of how to accomplish a process was addressed. To be able to understand the phenomena of scaffolding in personal learning environments and ePortfolios in a vocational teacher education context, it is necessary to identify the objects of the scaffolding. In this case, the objects of scaffolding are those parts of the students' work for which they need support.

\subsection{The Self-Determination Theory in Educational Settings}

In the context of teacher education, Self-Determination Theory (SDT) is attracting a growing level of interest from ePortfolio researchers (Chittum, 2018; Chye et al., 2012). For example, Chittum (2018) found that making a course-based ePortfolio can positively impact student teachers' motivation and demonstrates their higher-order thinking processes. SDT has been used as a theoretical framework in designing an online course intended to improve learner motivation, engagement and retention (Martin et al., 2018). These studies have prompted an interest in investigating students' motivation to complete ePortfolios and how they benefit from them.

According to Ryan and Deci (2000), motivation is important because it prompts acts that are based on satisfying individuals' psychological needs - specifically, competence, autonomy and relatedness and when these psychological needs are satisfied, self-motivation and wellbeing are enhanced in turn. SDT highlights the importance of inner resources for personality development and behavioural self-regulation (Ryan et al., 1997). Motivation varies from internal motivation to act to externally pressured activities. These are studied as conditions which cause intrinsic and extrinsic motivation (Ryan \& Deci, 2000). Ryan and Deci (2000) explained that intrinsic motivation is seen as the inherent satisfaction of an activity itself, 
the completion of which provokes interest and brings joy: Intrinsically motivated learning activities do not depend on external rewards. Extrinsic motivation, on the other hand, refers to activities undertaken in order to attain separable outcomes, e.g. acts that are driven by the value of the learning activity (Ryan \& Deci, 2000). Ryan and Deci (2000) divided extrinsic motivation into four different categories according to regulation styles, which differed in their level of perceived control. The first style is called extrinsic regulation, in which one is controlled by extrinsic recompense. Next is introjected regulation, where the student feels as though he or she has little autonomy due to feeling pressured to engage in an activity. The third style, identified regulation, focuses on feeling some sense of autonomy, as a result of which a student perceives the personal importance of an activity as being tied to career goals. The last style, integrated regulation, is achieved when a student's actions have become self-determined and the student has internalised learning (cf. Jacobi, 2018). Because students are expected to be self-determined and motivated to learn, their orientation to learning must be examined. Ryan and Deci's (2000) SDT explains this orientation as reaching one of three levels: impersonal, controlled and autonomous orientation. Autonomously oriented students find learning objectives important for their development and personal growth.

Reeve and Halusic (2009) stated that SDT emphasises the instructional task of vitalising a student's inner motivational resources. According to SDT, motivation exists along a continuum; this theory helps researchers understand student motivation and engagement arising from that motivation (Reeve, 2012). Furthermore, the theory can be used to identify a student's inner motivational resources and present recommendations as to how teachers can involve, cultivate and vitalise these resources (Niemiec \& Ryan, 2009).

\section{Methods}

\subsection{Context of the Study}

In the country under the study, vocational teacher studies include 60 ECTS (European Credit Transfer System), which usually take one year to complete. Most students study part-time, as they are already working as teachers or in other positions in educational organisations, or in different professions and positions in companies. The teacher education curricula include topics such as education sciences, pedagogical studies, teaching guidance and assessment, building a community, practical teacher training, and development of personal expertise in pedagogy. Those student teachers who participated in these studies enrolled in a special teacher education program focused on, among other subjects, to digital approaches to learning and teaching methods. Digital tools were studied via a self-directed massive open online course (MOOC). 
The study was conducted with one vocational teacher student group during the academic year 2017-2018; it was guided by the Personal Learning Environment philosophy and utilised ePortfolios as workspaces and showcases. This means that the student teachers were able to build their ePortfolios in any digital environment they found relevant and interesting. They chose such applications as WordPress, Blogger, Wix and Google Sites as their ePortfolio environment which are all free to use. The student teachers themselves decided how public to make their ePortfolios: only to the lecturers and peers or anybody via the internet. The lecturers used an open-source digital environment (WordPress) to share learning assignments, instructions and learning materials. The lecturers instructed the student teachers to produce the following content for their ePortfolios: A learning diary to reflect lessons learned during the teacher studies and practical training period (relating only to their workspace); learning outcomes as artefacts of learning assignments focusing on vocational teachers' competence; and other relevant information about their own competence (showcase). The lecturers gave instructions to student teachers throughout the year, starting with instructions for workspace ePortfolios and later for a showcase ePortfolio in which student teachers could demonstrate their teaching competence to different audiences in a digital format. The instructions for the learning assignments included details of how to save artefacts in one's own workspace portfolio. More generalised instructions were included for showcase portfolios, because it was important that each ePortfolio reflected its creators' personal touch and discipline-specific view. The lecturers gave feedback and instructions for each learning assignment and at the end assessed the artefacts thestudents included in their ePortfolios. The feedback was given directly to the students via their ePortfolios. However, the lecturers offered only general instructions for the layout of the showcase ePortfolios and did not give feedback until the end of the study.

\subsection{The Participants}

The participants consisted of 14 female and 6 male participants, whose ages varied between 31 and 54 years. They represented all disciplines of vocational education, from upper secondary vocational education and training to lecturers at universities of applied sciences. For upper secondary vocational education and training, the following disciplines were represented: ICT, business and management, tourism and catering, early childhood education, forestry, the textile industry and health care. The participants who represented universities of applied sciences were from disciplines such as communication and information technologies, art, education, craft, graphic design and social sciences. Participants' experience of vocational teacher's work varied from no experience to five years of experience; the average length of experience was 1.5 years. Eight participants were working as teachers and five were employed in other positions in educational institutions; seven worked outside the educational field. 
Fourteen of the participants had a master's degree in one of the above mentioned disciplines, while six had a bachelor's degree. All participants gave their consent for the collected data to be used for research purposes.

\subsection{Data Collection}

The data were collected from focus group discussions based on predefined questions. The focus group sessions were conducted at the end of the participants' teacher studies and all were conducted at the same time. The group of participants was divided into four smaller groups, each of which was asked to take part in a dialogue and answer the same questions. Each of the groups named a chair who read out the questions and took care that all of the questions were discussed. The length of the discussions varied, taking 36, 42, 46 and $56 \mathrm{mi}-$ nutes, respectively. All of the participants in each group took part in the discussions. The dialogues of the small groups were recorded using a voice recorder. The questions related to the participants' motivation to compose an ePortfolio, how they understood their competence to be represented in their ePortfolio, and what kind of scaffolding they recommended to their lecturers. The questions concerning scaffolding were defined according to the idea of distributed scaffolding (Tabak, 2004). The questions related to motivation were based on Ryan and Deci's (2000) definitions of extrinsic and intrinsic motivation. The following questions were asked in the focus group discussions:

- What inspired me to create an ePortfolio?

- What kind of competence is illustrated by my ePortfolio?

- How do ePortfolios work in documenting and assessing the learning process?

- How did my ePortfolio promote my learning?

- How did I demonstrate the way I work and collaborate with my students?

- What kind of scaffolding is needed from a lecturer while working with ePortfolios?

- I was/was not inspired and motivated by the following aspects of the ePortfolio process:

- obligatoriness

- freedom to choose a form and tool

- demonstrating competencies

- setting my own goals

- empowerment

- grade 
- process

- expectations

- changes in competencies and ways of thinking as well as development

- a tool for learning and support

- a new way to structure my development and competencies

The data were created in the format of a dialogue, which means that the participants worked with each other's comments and words in an effort to clarify everything which was said. They also asked each other further questions to clarify their shared understanding of each question and related topics.

\subsection{Data Analysis}

The recorded group discussions were transcribed and then transcriptions were analysed using NVivo software. The data were read through several times and the answers (nodes) were categorised according to the research questions. Each individual comment was counted as one item. The unit of analysis was any phrase, sentence or another expression of words that featured the meaning related to the phenomena.

The analysis was conducted in three phases according to the research questions. The first author conducted analyses using NVivo software, which were then examined several times together with the three other authors. All authors agreed on the final categorisations. During the discussion, the participants mixed up issues related to workspace portfolios and showcase portfolios, so these were categorised as a single ePortfolio.

The two first phases of the qualitative analyses were conducted using abductive analysis by gathering information from focus group discussions, reading theory, working with data and active inquiry combining theory-based and data-grounded approaches (Tavory \& Timmerman, 2014).

The first question explored was "what practices were used to create an ePortfolio as described by the students?" The data were categorised according to the types of practices and the following main categories emerged: 1) practices of creating an ePortfolio; and 2) practices of demonstrating a vocational teacher's competence in an ePortfolio.

During the second phase of the qualitative analysis, the participants were asked what kind of scaffolding they found to be important when making an ePortfolios during their studies. Their various suggestions were the data that were defined as categories describing types of supportive methods. The main categories were defined by the objects of scaffolding as 1) methods of composing an ePortfolio and 2) methods of illustrating a competence using an ePortfolio. 
The third phase of the qualitative analysis focused on the participants' discussion of motivation to learn and to represent their vocational teacher's competence in their ePortfolio. Deductive analysis was used to study the relationship between the data and existing theory (Schreier, 2012), and Ryan and Deci's (2000) SDT was used to study the extrinsic and intrinsic motivation manifested in each regulation style and orientation. This theory is described in Table 3 below, which also explains the analysis categories.

\subsection{Findings}

Practices for Creating an ePortfolio, as Described by the Participants

The practices for creating an ePortfolio are listed in Table 1. These concerned 1) the practices involved in creating an ePortfolio and 2) the practices involved in representing a vocational teacher's competence in an ePortfolio.

The highest number of nodes regarded the practices involved in creating an ePortfolio by writing reflections in a learning diary. These included activities such as learning to reflect on one's work and the kind of lessons learned during teacher studies. However, there were only a few nodes of reflection practices that measured personal growth as a teacher via a learning diary. Using digital tools by testing different kinds of tools independently for documentation and ePortfolio activities also played a big role in the practices involved in creating an ePortfolio. There were only a few nodes related to lecturers providing feedback on and assessing the creation of ePortfolios.

Concerning the practices of documenting vocational teachers' competence in an ePortfolio, most of the activities mentioned related to understanding the difference between a workspace ePortfolio and a showcase ePortfolio. However, there were only a few such nodes. There were a variety of approaches regarding which teachers' competencies can be documented in ePortfolios, such as teaching activities in a classroom or online, received feedback and assessment, and pedagogical competence and other competencies. Only a few nodes concerned the audience and how to show an ePortfolio to others. 
Table 1: The Practices Involved in Creating an ePortfolio, as Described by Students

\begin{tabular}{|c|c|c|c|}
\hline Main Categories & Types of Practices & Description of Items & Examples of the Data \\
\hline \multirow[t]{8}{*}{ Practices involved in creating an ePortfolio (61) } & Reflections recorded in a learning diary (25) & $\begin{array}{l}\text { Personal growing process as a } \\
\text { teacher via a learning diary (4) }\end{array}$ & $\begin{array}{l}\text { "I think my ePortfolio shows my own development and } \\
\text { growth as a teacher." }\end{array}$ \\
\hline & & How to do reflection (12) & $\begin{array}{l}\text { "Learning to do the reflection. If I had not written it anywhe- } \\
\text { re, I would not have reflected on and thought about these } \\
\text { situations and occasions." }\end{array}$ \\
\hline & & Lessons learned (9) & "What I have learned here during the year." \\
\hline & Using digital tools (18) & Testing tools (14) & $\begin{array}{l}\text { "Would it be a part of the process of one searching for tools } \\
\text { on one's own, thinking and testing." }\end{array}$ \\
\hline & & Documentation tools (4) & $\begin{array}{l}\text { "It is a supportive tool where one's thoughts can be saved, not } \\
\text { only in order to memorise them." }\end{array}$ \\
\hline & Doing learning assignments (6) & $\begin{array}{l}\text { All learning assignments comple- } \\
\text { ted and saved in an ePortfolio (6) }\end{array}$ & "All of one's own artefacts are linked." \\
\hline & Actively following up peers' ePortfolios (9) & Tips from peers' ePortfolios (9) & $\begin{array}{l}\text { "It was clear when I saw someone else's showcase that was } \\
\text { accepted: I thought, 'Oh, this is like a CV but extended." }\end{array}$ \\
\hline & Receiving lecturer's feedback and assessment (3) & Tips from lecturers $(3)$ & $\begin{array}{l}\text { "The feedback was given as a commentary on the text, so it } \\
\text { was clear what was the feedback about. It worked well." }\end{array}$ \\
\hline \multirow{3}{*}{$\begin{array}{l}\text { Practices involved in representing a vocational } \\
\text { student teacher's competence in an ePortfolio } \\
\text { (48) }\end{array}$} & $\begin{array}{l}\text { Understanding the difference between a work- } \\
\text { space and a showcase (11) }\end{array}$ & Portfolio as a process (6) & $\begin{array}{l}\text { "Making a showcase without a workspace portfolio is much } \\
\text { more difficult." }\end{array}$ \\
\hline & & $\begin{array}{l}\text { Workspace and showcase docu- } \\
\text { mentation (5) }\end{array}$ & $\begin{array}{l}\text { "I sort of extended my workspace portfolio into a showcase } \\
\text { portfolio." }\end{array}$ \\
\hline & $\begin{array}{l}\text { Understanding the difference between a work- } \\
\text { space and a showcase (11) }\end{array}$ & Portfolio as a process (6) & $\begin{array}{l}\text { "Making a showcase without a workspace portfolio is much } \\
\text { more difficult." }\end{array}$ \\
\hline
\end{tabular}




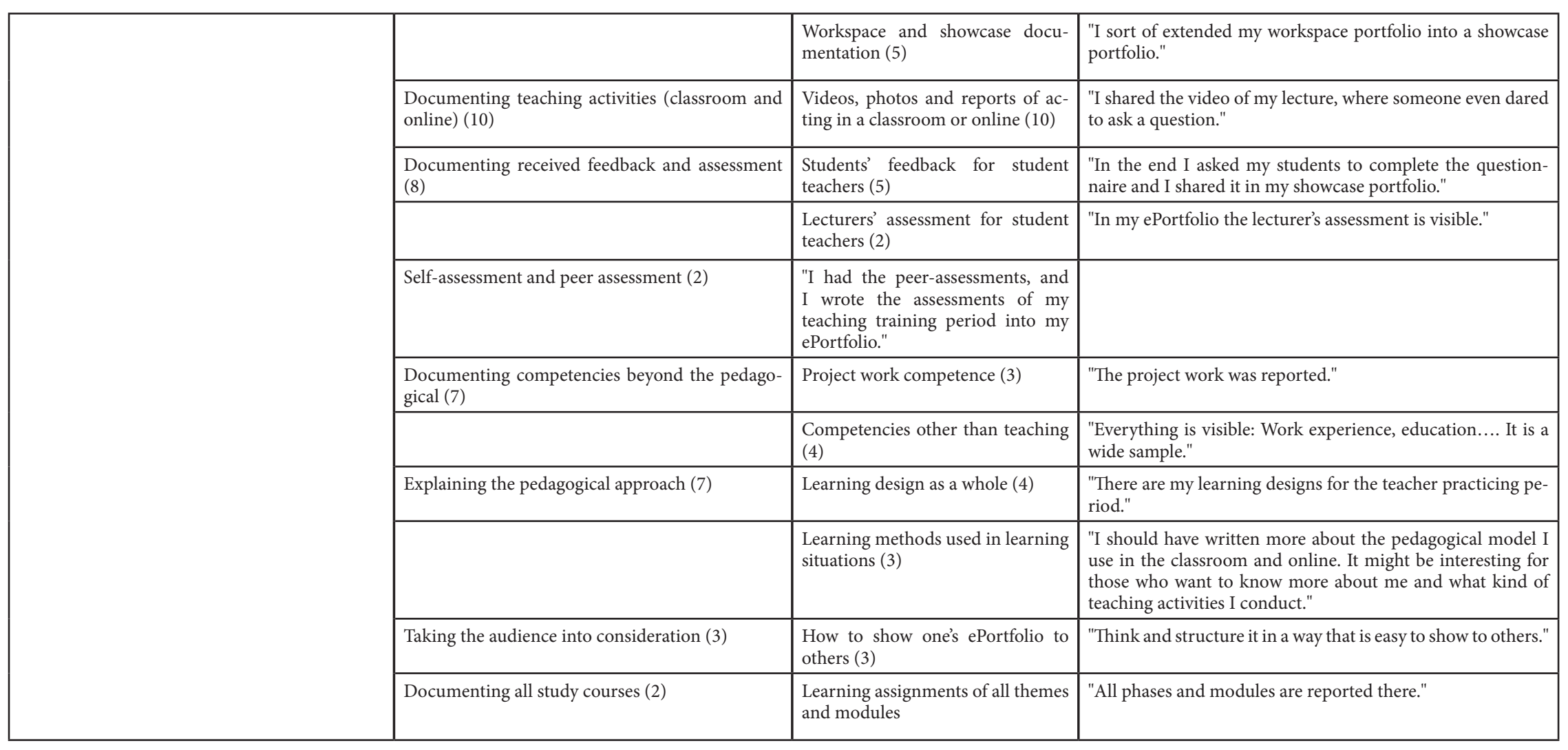


Participants' Suggestions Regarding how to Organise Scaffolding for Students Making ePortfolios

The data included several suggestions about how to provide scaffolding in making ePortfolios. The two categories of these suggestions were 1) supportive methods of composing an ePortfolio and 2) supportive methods of illustrating a vocational teacher's competence through an ePortfolio. All of the expected objects of scaffolding from lecturers are presented in Table 2.

The suggestions for supportive methods of creating an ePortfolio mainly concerned collaborations with fellow students. The suggestions were to implement collaborative learning processes, make students follow and comment on their peers' ePortfolios and giving presentations more often in order to prompt discussions of how to create an ePortfolio. The less-often-mentioned recommendations were having more feedback, commentary and assessments from the lecturers in order to improve ePortfolios as well as having more detailed instructions how to continue. Support for personal growth, getting clear instructions for learning assignments and getting instructions on how to use web tools in alternative ways were also mentioned as suggestions for supporting students composing an ePortfolio.

The recommendations for supportive methods for documenting a vocational teacher's competence in an ePortfolio also included an orientation session prior to beginning work on an ePortfolio, setting learning objectives and assessment criteria for an ePortfolio, explaining what kind of competence to show and what kind of audience the ePortfolios should be presented to. Related to this, the participants suggested giving instructions for the processes of creating workspace and showcase ePortfolios, starting with an explanation of the difference between the two. Giving examples of good ePortfolios was also mentioned.

Scaffolding providers were found to be lecturers, peers, and given instructions related to learning assignments. 
Table 2: Recommendations for Important Support for Making an ePortfolio Based on the Participants' own Experiences

\begin{tabular}{|c|c|c|c|}
\hline Main Categories & Types of Support & Description of Items & Examples of Data \\
\hline \multirow[t]{8}{*}{$\begin{array}{l}\text { Supportive methods of creating an ePortfolio } \\
\text { (91) }\end{array}$} & Collaboration with peer-student teachers (49) & $\begin{array}{l}\text { Using a collaborative learning process in peer- } \\
\text { group work (17) }\end{array}$ & $\begin{array}{l}\text { "The peer-learning could have been utilised in } \\
\text { some way." }\end{array}$ \\
\hline & & $\begin{array}{l}\text { Following and commenting on each other's } \\
\text { ePortfolios (16) }\end{array}$ & $\begin{array}{l}\text { "It would be nice to have had some kind of com- } \\
\text { munication there." }\end{array}$ \\
\hline & & $\begin{array}{l}\text { Presentation and discussion with one's peer } \\
\text { group (16) }\end{array}$ & $\begin{array}{l}\text { "There should have been presentations of work- } \\
\text { space ePortfolios at some point in the middle o } \\
\text { the season." }\end{array}$ \\
\hline & $\begin{array}{l}\text { Lecturers' feedback, comments and assessments } \\
\text { (15) }\end{array}$ & $\begin{array}{l}\text { Feedback and suggestions for improvements and } \\
\text { how to continue (12) }\end{array}$ & $\begin{array}{l}\text { "We should have had some communication } \\
\text { while working on our ePortfolios. It is the } \\
\text { lecturer's role to show somehow that she/he fol } \\
\text { lows all of our common issues and to lead a dis } \\
\text { cussion about them." }\end{array}$ \\
\hline & & $\begin{array}{l}\text { Following those who might drop out of the } \\
\text { ePortfolio process (3) }\end{array}$ & $\begin{array}{l}\text { "If someone in the group is about to drop ou } \\
\text { and forget the whole thing, they should be noti } \\
\text { ced immediately and persuaded to pick up the } \\
\text { process again." }\end{array}$ \\
\hline & Getting support for personal growth (10) & $\begin{array}{l}\text { What is professional growth and how is it ac- } \\
\text { complished? (4) }\end{array}$ & $\begin{array}{l}\text { "Somehow give better instructions for reflection } \\
\text { and professional growth." }\end{array}$ \\
\hline & & $\begin{array}{l}\text { Creating a personal development plan in the be- } \\
\text { ginning and reflecting on it later (6) }\end{array}$ & $\begin{array}{l}\text { "We were instructed to make a development plan } \\
\text { (in the beginning), so what if there had been } \\
\text { second task at the end of the studies in which } \\
\text { you had to compare your present competence to } \\
\text { what it was in the beginning?" }\end{array}$ \\
\hline & Getting learning assignments (9) & $\begin{array}{l}\text { Clear learning assignments given for each topic } \\
\text { (5) }\end{array}$ & "Give even too clear instructions." \\
\hline
\end{tabular}




\begin{tabular}{|c|c|c|c|}
\hline & & Assignments given regularly (4) & $\begin{array}{l}\text { "Maybe some questions could be asked every } \\
\text { time, so that you have to document your respon- } \\
\text { ses in your ePortfolio on a regular basis." }\end{array}$ \\
\hline & Getting instructions on how to use web tools (8) & $\begin{array}{l}\text { Using more new alternative tools (e.g. vlogs, } \\
\text { voice recordings) (4) }\end{array}$ & $\begin{array}{l}\text { "We think that you could make a vlog, a blog in } \\
\text { video format." }\end{array}$ \\
\hline & & Being obliged to open an ePortfolio (2) & "Some part of the ePortfolio must be open." \\
\hline & & $\begin{array}{l}\text { Providing technical instructions (in a classroom) } \\
\text { (2) }\end{array}$ & $\begin{array}{l}\text { "Maybe a whole school day could be sacrificed } \\
\text { for making an ePortfolio, tools and other stuff." }\end{array}$ \\
\hline $\begin{array}{l}\text { Supportive methods of illustrating a vocational } \\
\text { student Teacher's competence through an ePort- } \\
\text { folio (39) }\end{array}$ & Attitude towards ePortfolio work (16) & $\begin{array}{l}\text { Having set learning objectives and assessment } \\
\text { criteria for ePortfolios (6) }\end{array}$ & $\begin{array}{l}\text { "Some kind of frame is needed in order to know } \\
\text { the minimum requirement; we need to know } \\
\text { what kind of content we need to build our ePort- } \\
\text { folios." }\end{array}$ \\
\hline \multirow[t]{6}{*}{ Teacher's competence through an ePortfolio (39) } & & Defining one's competence(s) (4) & $\begin{array}{l}\text { "What is the purpose of the ePortfolios: Are they } \\
\text { meant for us as a way of keeping track of what } \\
\text { we have learned or are they a means of selling } \\
\text { ourselves as part of a job application?" }\end{array}$ \\
\hline & & Identifying one's audience (3) & $\begin{array}{l}\text { "Making something like this without any clear } \\
\text { goal." }\end{array}$ \\
\hline & & How to start the process (3) & $\begin{array}{l}\text { "When the work starts is probably the most im- } \\
\text { portant aspect of getting started." }\end{array}$ \\
\hline & $\begin{array}{l}\text { Getting instructions on the process of creating a } \\
\text { workspace and showcase ePortfolios (13) }\end{array}$ & $\begin{array}{l}\text { Differences must be explained thoroughly in the } \\
\text { beginning (10) }\end{array}$ & $\begin{array}{l}\text { "This is it! Was it clear for us a year ago what this } \\
\text { was going to be?" }\end{array}$ \\
\hline & & $\begin{array}{l}\text { Start a showcase ePortfolio at the beginning of } \\
\text { a learning process together with a workspace } \\
\text { ePortfolio (3) }\end{array}$ & $\begin{array}{l}\text { "How about starting at the beginning from the } \\
\text { point that this will be a showcase ePortfolio. I } \\
\text { think it was not made clear to us what a work- } \\
\text { space is and what a showcase is." }\end{array}$ \\
\hline & Getting examples of an ePortfolio (10) & Provide examples of good ePortfolios & $\begin{array}{l}\text { "Our lecturers could take examples from our } \\
\text { showcases and use them to explain to the next } \\
\text { course that we started with this part a year ago. } \\
\text {...They have sample cases now." }\end{array}$ \\
\hline
\end{tabular}


Motivation to Learn and Demonstrate one's Competence Through an ePortfolio

Three sources of motivation were identified in the data: 1) Interest in portfolio activities/process; 2) one's teaching competence; and 3) digitalisation and technology. The categories used to analyse the participants' motivation are presented in Table 3.

The findings show that the most common motivation for working with ePortfolios was an interest, in general, to learn and a desire to make one's competences visible in an ePortfolio. The main orientation was controlled and non-self-determined, as the reason for wanting to complete an ePortfolio was that it was obligatory to do so in order to pass the course. However, some participants also demonstrated autonomous and intrinsic motivation was shown in the participants' personal interests and target-setting to learn teaching competence.

The motivation to demonstrate competence using an ePortfolio was discussed by mentioning aspects that are considered intrinsic. This was shown in the interest in personal growth as a vocational teacher. For example, one student said, "It is fruitful to think from time to time what kind of skills my teacher competence includes." At the same time, motivation to demonstrate one's competence in an ePortfolio was discussed by the participants in an extrinsic manner, because the ePortfolios were created for external purposes such as job applications. For example, another student commented: "It was nice to do it because I have applied for jobs many times and may do so again in the future, so this kind of ePortfolio could be used then instead of just a boring CV."

The explanations of motivations concerning digitalisation and technology were quite fragmented, but still showed an autonomous orientation which can be interpreted as relating to extrinsic motivation. The participants' comments highlighted that it was important to document artefacts according to their learning assignments and to adapt the learning objective to document their competence in a digital format. One student said for example: "It was good that there was one place to make the reflections. I utilised that already when we had to do those Open Badges and made those artefacts there and so on. So everything was not spread out."

Some participants mentioned in the focus group discussions that they were learning to use technology in a natural way which would continue to be useful once they had finished their studies. One participant mentioned: "And now we have digital tools we can really use, like Google Drive collaborative documents ... we don't need to make any extra effort to use those."

Intrinsic motivation was also demonstrated when a participant explained the new methods and learned technology: "First of all I was inspired that we started to work with ePortfolios and a kind of blog writing, as I have never done anything with blogs. So I was inspired by just the tool itself to start working on my ePortfolio." 
Table 3: Motivation to Learn and Demonstrate Competence in an ePortfolio According to the Self-Determination Theory (Ryan \& Deci, 2000)

\begin{tabular}{|c|c|c|c|c|}
\hline & \multicolumn{3}{|c|}{ Behaviour: Non-Self-Determined } & Self-Determined \\
\hline & Orientation: Controlled & & Orientation: & Autonomous \\
\hline $\begin{array}{l}\text { Category } \\
N=123\end{array}$ & $\begin{array}{l}\text { Extrinsic motivation / } \\
\text { external regulation and } \\
\text { introjection }\end{array}$ & $\begin{array}{l}\text { Extrinsic } \\
\text { motivation / } \\
\text { identification }\end{array}$ & $\begin{array}{l}\text { Extrinsic } \\
\text { motivation / } \\
\text { integration }\end{array}$ & Intrinsic motivation \\
\hline $\begin{array}{l}\text { Interest in } \\
\text { ePortfolio acti- } \\
\text { vities/process }\end{array}$ & 23 & & $\begin{array}{l}\text { Freedom to } \\
\text { choose web } \\
\text { tools }(8) \\
8\end{array}$ & $\begin{array}{l}\text { Personal interest in working with } \\
\text { ePortfolios as requested (6) } \\
\text { Personal target-setting and vision } \\
\text { (7) } \\
13\end{array}$ \\
\hline $\begin{array}{l}\text { One's teaching } \\
\text { competence }\end{array}$ & $\begin{array}{l}\text { Included as a part of studies } \\
\text { (1) }\end{array}$ & 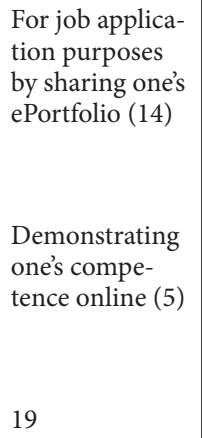 & & 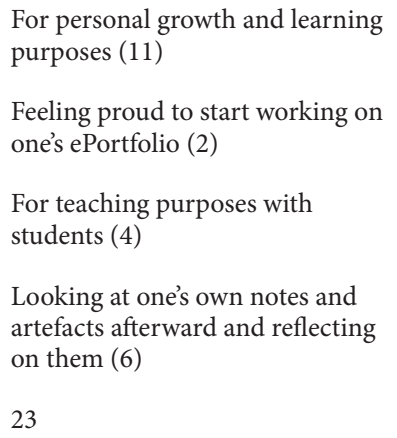 \\
\hline $\begin{array}{l}\text { Digitalisation } \\
\text { and technology }\end{array}$ & & $\begin{array}{l}\text { Open environ- } \\
\text { ments to de- } \\
\text { monstrate and } \\
\text { share compe- } \\
\text { tencies (5) } \\
\text { Documenting } \\
\text { artefacts related } \\
\text { to given assign- } \\
\text { ments (9) }\end{array}$ & $\begin{array}{l}\text { The ePortfolio } \\
\text { process starts } \\
\text { during studies } \\
\text { and continues } \\
\text { after (3) } \\
\text { Added value for } \\
\text { studies (2) } \\
\text { Natural use of } \\
\text { technology du- } \\
\text { ring studies and } \\
\text { after (6) }\end{array}$ & $\begin{array}{l}\text { Being inspired by new methods } \\
\text { and technology (5) } \\
\text { Reflections on one's own develop- } \\
\text { ment which can be read later and } \\
\text { learned from (6) }\end{array}$ \\
\hline 36 & & 14 & 11 & 11 \\
\hline
\end{tabular}




\section{Discussion}

To summarise the practices student teachers used to make their ePortfolios (research question 1), the most common practice mentioned was recording reflections in a learning diary. Testing and using digital tools independently were also frequently mentioned. The participants used different approaches to document their vocational teachers' competence, such as documenting visual evidence of teaching activities in a classroom or online and, documenting received feedback and pedagogical and other competencies. The possible audiences of the participants' ePortfolios were rarely mentioned.

The participants offered many suggestions regarding how to organise scaffolding (research question 2), the most important of which were the various methods of creating an ePortfolio. Collaborative learning using several learning practices, including following and commenting on peers' ePortfolios and giving presentations on one's own ePortfolio more often were found to be very important. Next was a request for more feedback and assessments from the lecturers, which were expected to include instructions on how to improve and continue ePortfolio work. The recommendations for supportive methods of documenting a vocational teacher's competence in an ePortfolio focused on an orientation that would include set learning objectives, assessment criteria, instructions for what kind of competence to show and who the ePortfolios would be viewed by.

The stress of scaffolding objects varied. There were three objects of scaffolding that student teachers recommended but did not feel they had: 1) support for personal growth and how to compose related topics in ePortfolios; 2) examples of good ePortfolios in order to illustrate one's competence; and 3) clear assessment criteria.

The aspects of scaffolding relating to making competence visible through ePortfolios mentioned by the participants in their recommendations were in line with the perspective of distributed scaffolding (Lajoie, 2005; Tabak, 2004). Various scaffolding providers were mentioned as being important in scaffolding, including the lecturer, peers and, written instructions and other materials. In addition, during the teacher training period in educational institution workplace mentors were found to be a scaffolding provider, as well as the participants' own students through giving their feedback on the teaching activities conducted. Similar to Parker et al. (2012), it was found that the student teachers needed scope, guidance, timing, alignment with standards, reflection on their growth and instructions for making ePortfolios visible to a wider audience in order to make the process meaningful. This finding confirms Lakkala et al. (2005) conclusion about online scaffolding that giving general instructions is not sufficient. For example, the participants found it difficult to understand the role of a showcase ePortfolio by following general instructions. Roberts (2018) found it necessary to provide more scaffolding to students regarding the ePortfolio audience and content for lifelong learning purposes. These perspectives emerged in the students' focus group discussions also in our study. However, all of the earlier studies on ePortfolios mentioned above 
concerned contexts where a certain digital application as an ePortfolio tool was provided by an educational institution or teacher, and thus they did not fully follow the PLE philosophy. Roberts (2018), Masters (2013), Douglas et al. (2019) and Parker et al. (2012) reported that students found it difficult to use these particular indicating that it needed more scaffolding. In this study, however, the participants had no difficulties with digital tools even when they were given the freedom to choose them, in accordance with the PLE philosophy. Digital tools were integrated in several ways in the participants' studies and the ePortfolio created a beneficial environment to use them in various ways. The participants also found the selfdirected online course (MOOC) a good way to learn to use digital tools and digitalisation. This inspired them to test many kinds of digital tools and use them during the course and in their daily work.

To summarise the issues which motivate student teachers to create an ePortfolio (research question 3), the most frequently mentioned sources of motivation were to pass the course and to achieve personal growth by developing one's teaching competence. The next-mostoften mentioned factor was to use the ePortfolio for career promotion purposes and in job applications. The participants demonstrated a self-determined orientation to learning and documenting their competencies in their ePortfolios, but nonetheless they completed their ePortfolios because it was a compulsory element of their studies, so in this their motivation was also control-orientated and regulation was introjected. The participants found they were motivated to create their ePortfolios because they can be used for job application purposes and as a means of demonstrating their competence in a modern way to prospective employers. This is an important motivation, given the necessity of promoting oneself in the labour market, and confirmed the results of Mobarhan et al. (2015), who also studied intrinsic and extrinsic motivations to create ePortfolios. This result also emphasises the significance of some student teachers being strongly self-determined and being intrinsically motivated to work on ePortfolios. However, the results of this study also indicated that the participants' orientation varied.

Several recent studies on Finnish vocational teacher education have assessed scaffolding students using digital environments and concluded that improving scaffolding was necessary when the new possibilities are afforded by digital environments (cf. Brauer et al., 2019; Korhonen et al., 2019a, 2019b; Ruhalahti, 2019). Although ePortfolios seem to motivate students to demonstrate their competencies in vocational teacher education, more modern approaches may be still implemented.

Figure 1 presents an overview of the objects of scaffolding as well as methods of scaffolding which motivate vocational student teachers to work with ePortfolios under various orientations. It begins with controlled orientation-student teachers who are not yet selfdetermined learners. Next is autonomous orientation and intrinsic regulation, those student teachers who have become self-determined learners. Figure 1 illustrates by whom the 
scaffolding is given (scaffolding provider) in each method of scaffolding also by different motivation orientation. As peers were found to be the most important support for working with ePortfolios they are suggested to consider as scaffolding providers in each motivation orientations. When students achieve autonomous orientation in their personal growth and develop their own teacher competence they are able to work alone by utilising internalised practices and strategies (Walqui, 2006).

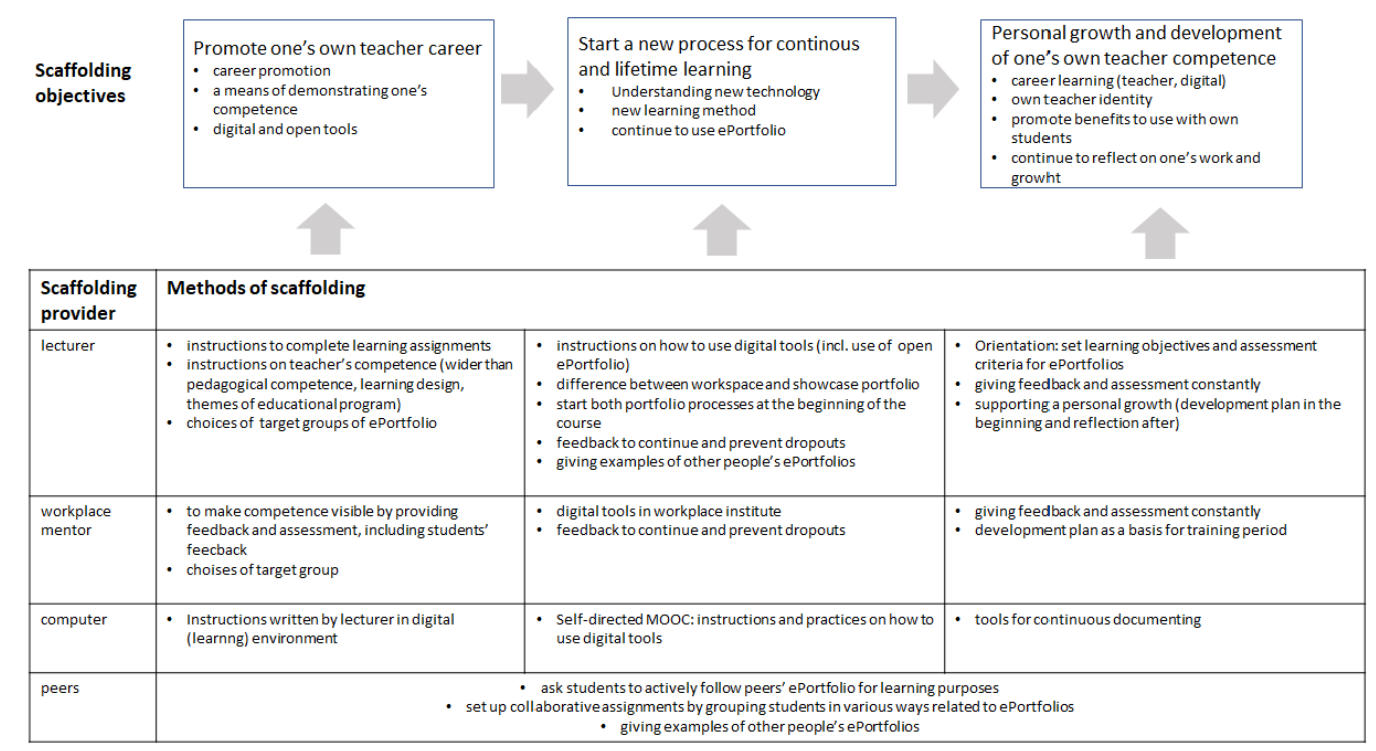

Figure 1: Scaffolding Objects and Methods of Scaffolding With Motivational Orientations of Vocational Student Teachers to Learn and Document Their Competencies in Their ePortfolios

This study focused on the voice of student teachers who worked with ePortfolios during their studies. Another avenue of research would be to study their ePortfolios in order to find how they have followed the instructions and how the methods of scaffolding influenced them. Learning objectives and assessment criteria are also recommended to focus on the future studies of training vocational student teachers as indicated by the findings of the present study. In the future, it might be relevant to study how scaffolding can be faded and how students proceed after that. This study did not address the personal needs of each student for scaffolding, so that is another issue that could be explored in future research. It might also be interesting to explore how student teachers work with their ePortfolios after their studies: Were they offered any jobs based on their ePortfolio, have they documented their progress with their ePortfolios and do they feel that they need them for continuous learning? 


\section{Acknowledgement}

This study was a part of the Empowering ePortfolio Process (Cooperation for innovation and the exchange of good practices), partly funded by the Erasmus+ program 2016-2018.

\section{References}

Barrett, H. C. (2007). Researching electronic portfolios and learner engagement: The REFLECT initiative. Journal of Adolescent \& Adult Literacy, 50(6), 436-449. https://doi.org/10.1598/JAAL.50.6.2

Barrett, H. C. (2010). Balancing the two faces of ePortfolios. Educação, Formação \& Tecnologias, 3(1), 6-14. Educom. http://eft.educom.pt/index.php/eft/article/viewFile/161/102

Brauer, S., Korhonen, A.-M., \& Siklander, P. (2019). Online scaffolding in digital open badge-driven learning in vocational teacher education. Educational Research, 61(1), 53-69. https://doi.org/10.1 080/00131881.2018.1562953

Cambridge, D. (2008). Layering networked and symphonic selves: A critical role for e-portfolios in employability through integrative learning. Campus-Wide Information Systems, 25(4), 244-262.

Cheng, G., \& Chau, J. (2013). A study of the effects of goal orientation on the reflective ability of electronic portfolio users. The Internet and Higher Education, 16, 51-56. https://doi.org/10.1016/j. iheduc.2012.01.003

Chittum, J. R. (2018). The theory-to-practice ePortfolio: An assignment to facilitate motivation and higher-order thinking. International Journal of ePortfolio, 8(1), 27-42.

Chye, S., Liau, A., \& Liu, W. (2012). Student teachers' motivation and perceptions of e-Portfolio in the context of problem-based learning. The Asia-Pacific Education Researcher, 22(4), 367-375. https:// doi.org/10.1007/s40299-012-0022-4

Dabbagh, N. (2003). Scaffolding: An important teacher competency in online learning. TechTrends, 47(2), 39-44. https://doi.org/10.1007/BF02763424

de Olivieira, L., \& Athanases, S. (2017). A framework to reenvision instructional scaffolding for linguistically diverse learners. The Journal of Adolescent \& Adult Literacy, 61(2), 123-129. https://doi. org/10.1002/jaal.663

Donato, R. (1994). Collective scaffolding in second language learning. In J. P. Lantolf \& G. Appel (Eds.), Vygotskian approaches to second language research (pp. 33-56). Albex.

Douglas, M., Peecksen, S., Rogers, J., \& Simmons, M. (2019). College students' motivation and confidence for ePortfolio use. International Journal of ePortfolio, 9(1), 1-16.

Fiedler, S., \& Väljataga, T. (2013). Personal learning environments: A conceptual landscape revisited. eLearning Paper no. 35. Academia. https://www.academia.edu/16241614/Personal_Learning_ Environments_A_conceptual_landscape_revisited

Jacobi, L. (2018). What motivates students in the online communication classroom? An exploration of self-determination theory. Journal of Educators Online, 15(2). https://doi.org/10.9743/ jeo.2018.15.2.1

Korhonen, A.-M., Lakkala, M., \& Veermans, M. (2019b). Identifying student teachers competence using an ePortfolio. European Journal of Workplace Innovation, 5(1). https://doi.org/10.46364/ejwi. v5i1.512 
Korhonen, A.-M., Ruhalahti, S., \& Veermans, M. (2019a). The online learning process and scaffolding in student teachers' personal learning environments. Education and Information Technologies, 24(1), 755-779. https://doi.org/10.1007/s10639-018-9793-4

Lajoie, S. (2005). Extending the scaffolding metaphor. Instructional Science, 33, 541-557. https://doi. org/10.1007/s11251-005-1279-2

Lakkala, M., Muukkonen, H., \& Hakkarainen, K. (2005). Patterns of scaffolding in computer-mediated collaborative inquiry. Mentoring \& Tutoring: Partnerships in Learning, 13, 281-300. https:// doi.org/10.1080/13611260500107457

Lave, J., \& Wenger, E. (1991). Situated learning. Legitimate peripheral participation. Cambridge University Press.

Martin, N., Kelly, N., \& Terry, P. (2018). A framework for self-determination in massive open online courses: Design for autonomy, competence, and relatedness. Australasian Journal of Educational Technology, 34(2), 35-55. https://doi.org/10.14742/ajet.3722

Masters, J. (2013). Scaffolding pre-service teachers representing their learning journeys with ePortfolios. Journal of Learning Design, 6(1), 1-9. https://doi.org/10.5204/jld.v6i1.115

Michaelsen, L., \& Sweet, M. (2011). Team-based learning. New Directions for Teaching and Learning, 128, 41-51. https://doi.org/10.1002/tl.467

Mobarhan, R., Rahman, A., \& Majidi, M. (2015). Electronic portfolio motivational factors from students' perspective: A qualitative study. Knowledge Management \& E-Learning, 7(2), 265-279. https://doi.org/10.34105/j.kmel.2015.07.017

Niemiec, C. P., \& Ryan, R. M. (2009). Autonomy, competence, and relatedness in the classroom: Applying self-determination theory to educational practice. Theory and Research in Education, 7, 133-144. https://doi.org/10.1177/1477878509104318

Papier, J. (2019). Book review: Teachers and teaching in vocational and professional education. International Journal for Research in Vocational Education and Training, 6(1), 97-101. https://doi. org/10.13152/IJRVET.6.1.5

Parker, M., Ndoye, A., \& Ritzhaupt, A. (2012). Qualitative analysis of student perceptions of e-Portfolios in a teacher education program. Journal of Digital Learning in Teacher Education, 28(3), 99-107. https://doi.org/10.1080/21532974.2012.10784687

Plaisir, J., Hachey, A., \& Theilheimer, R. (2011). Their portfolios, our role: Examining a community college teacher education digital portfolio program from the students' perspective. Journal of Early Childhood Teacher Education, 32(2), 159-175. https://doi.org/10.1080/10901027.2011.572231

Puntambekar, S., \& Hübscher, R. (2005). Tools for scaffolding students in a complex learning environment: What have we gained and what have we missed? Educational Psychologist, 40(1), 1-12. https://doi.org/10.1207/s15326985ep4001_1

Reeve, J. (2012). A self-determination theory perspective on student engagement. In S. L. Christenson, A. L. Reschly \& C. Wylie (Eds.), Handbook of research on student engagement, (pp. 149-172). Springer. https://doi.org/10.1007/978-1-4614-2018-7_7

Reeve, J., \& Halusic, M. (2009). How K-12 teachers can put self-determination theory principles into practice. Theory and Research in Education, 7, 145-154. https://doi.org/10.1177/1477878509104319

Roberts, P. (2018). Developing reflection through an ePortfolio-based learning environment: Design principles for further implementation. Technology, Pedagogy and Education, 27(3), 313-326. https://doi.org/10.1080/1475939X.2018.1447989 
Ruhalahti, S. (2019). Redesigning a pedagogical model for scaffolding dialogical, digital and deep learning in vocational teacher education. Doctoral dissertation, University of Lapland. https://lauda. ulapland.fi/handle/10024/63734

Ryan, M., \& Deci, E. (2000). Self-determination theory and the facilitation of intrinsic motivation, social development, and well-being. American Psychologists, 55(1), 68-78. https://doi.org/10.1037/0003066X.55.1.68

Ryan, R., Kuhl, J., \& Deci, E. (1997). Nature and autonomy: Organizational view of social and neurobiological aspects of self-regulation in behavior and development. Development and Psychopathology, 9, 701-728. https://doi.org/10.1017/s0954579497001405

Schreier, M. (2012). Qualitative content analysis in practice. Sage.

Stone, C. A. (1998). Should we salvage the scaffolding metaphor? Journal of Learning Disabilities, 31, 409-413. https://doi.org/10.1177/002221949803100411

Säljö, R. (2009). Learning, theories of learning, and units of analysis in research. Educational Psychologist, 44(3), 202-208. https://doi.org/10.1080/00461520903029030

Tabak, I. (2004). Synergy: A complement to emerging patterns of distributed scaffolding. The Journal of the Learning Sciences, 13(3), 305-335. https://doi.org/10.1207/s15309jls1303_3

Tavory, I., \& Timmermans, S. (2014). Abductive analysis: Theorizing qualitative research. University of Chicago Press.

Vygotsky, L. S. (1978). Mind in society. The development of higher psychological processes. Harvard University Press. https://doi.org/10.2307/j.ctvjf9vz4

Walqui, A. (2006). Scaffolding instruction for English language learners: A conceptual framework. International Journal of Bilingual Education and Bilingualism, 9(2), 159-180. https://doi. org/10.1080/13670050608668639

Wheeler, S. (2015). Learning with 'e's: Educational theory and practice in the digital age. Crown House Publishing.

Wood, D., Bruner, J., \& Ross, G. (1976). The role of tutoring in problem solving. The Journal of Psychology and Psychiatry, 11(2), 89-100. https://doi.org/10.1111/j.1469-7610.1976.tb00381.x

\section{Biographical Notes}

Anne-Maria Korhonen, MSc (economics) is a doctoral student in University of Turku, Finland. She works as a teacher trainer and senior lecturer in HAMK University of Applied Sciences, The School of Professional Teacher Education.

Sanna Ruhalahti is a Ph.D. and works as a senior lecturer at The HAMK UAS, School of Professional Teacher Education. Her research interests focus on authentic, dialogical and collaborative knowledge construction in digital environments in order to promote deep learning.

Minna Lakkala, Ph.D., Title of Docent in Educational Psychology, works as a researcher at the University of Helsinki. She investigates creative knowledge practices and technologyenhanced teaching and learning in all educational levels. 
Associate professor Marjaana Veermans, Ph.D., has expertise in motivational aspects of learning environments. The methodological expertise of Veermans is in conducting research in authentic learning settings, combining both quantitative and qualitative sets of data. 